\title{
Extraction of Pigments from Rhodotorula Species of Dairy Environment
}

\author{
K. Shivalkar Yadav* and R. Prabha \\ Department of Dairy Microbiology, Dairy Science College, \\ KVAFSU, Hebbal, Bengaluru -560024, India; shivalkaryadav@gmail.com
}

\begin{abstract}
Carotenoids are an attractive class of tetraterpenoid pigmented compounds naturally produced by diverse organisms including plants and numerous fungi and bacteria. Colour of the commercial products play a vital role to attract the consumers and also represent the quality of the products. Rhodotorula minuta $\mathrm{RAI}_{3}, R$. acheniorum $\mathrm{RC}_{2}, R$. minuta $\mathrm{RY}_{1}$ and Rhodotorula sp $\mathrm{RA}_{2}$, isolated from dairy environment and further characterized were selected for pigment production. Out of the three Rhodotorula isolates, $R$. minuta $\mathrm{RAI}_{3}$ showed high yield of carotenoid pigment (4.412 $\mu \mathrm{g} / \mathrm{g}$ of dry cell mass) in coconut water as natural medium compared to semi synthetic medium Malt Yeast Extract broth (MYEB) and solid state medium rice on $6^{\text {th }}$ day of incubation at $30{ }^{\circ} \mathrm{C}$. R. minuta $\mathrm{RAI}_{3}$ recorded high yield of both extra and intracellular pigment (2.877 and $4.412 \mu \mathrm{g} / \mathrm{g}$ of dry cell mass).
\end{abstract}

Keywords: Carotenoids, Extracellular, Extraction, Intracellular Pigment, Microbial Pigments

\section{Introduction}

Carotenoids are natural pigments responsible for the pleasing colours of many foods and have important biological activities. Some carotenoids are precursors of vitamin A which have beneficial effects on human health including enhancement of the immune system and reduction of the risk for degenerative diseases such as cancer, cardiovascular diseases and cataract GarridoFernande $z^{4}$. Thus, carotenoids constitute one of the most valuable classes of compounds for industrial applications, e.g. in pharmaceutical, chemical, food and feed industries. Colour is an important attribute that determines consumers acceptance of foods. Recently, a large market of pigments is actually satisfied through synthetic way. However, in food and cosmetic industries, the application of chemically synthetic carotenoids is restricted because of their toxicity Maldonade ${ }^{7}$.

Traditionally, carotenoids were extracted from plants such as annatto, paprika and saffron that showed variation in the quality during batch wise production whereas today microbial carotenoids have attracted much attention because of the ease of increasing production by environmental and genetic manipulation. Attention of researchers is on the isolation of carotenoids from biological sources such as Rhodotorula mucilaginosa ${ }^{1}, R$. rubrum and $R$. sphaeroides $^{2}$, Chlorella zofingiensis ${ }^{8}$ and Haematococcus pluvialis $^{3}$ of the green microalgae. The cost of carotenoids production by fermentation can be minimized by optimizing its process, using highly pigment-producing microorganisms especially Rhodotorula cultured in cheap industrial by-products as nutrient sources ${ }^{1}$.

Rhodotorula is carotenoid synthesizing yeast, part of the Basidiomycota phylum, easily identifiable by distinctive yellow, orange/red colonies. The main carotenoids produced in Rhodotorula species are torularhodin, torulene and $\gamma$-carotene and minute quantity of $\beta$-carotene ${ }^{5}$. The present study was taken up to extract the pigment from Rhodotorula minuta $\mathrm{RAI}_{3}, R$. acheniorum $\mathrm{RC}_{2}$ Rhodotorula sp $\mathrm{RA}_{2}$ and Rhodotorula sp $\mathrm{RY}_{1}$ obtained from various dairy environmental sources. 


\section{Materials and Methods}

\subsection{Cultures and their Maintenance}

Rhodotorula minuta $\mathrm{RAI}_{3}$, R. acheniorum $\mathrm{RC}_{2}$, Rhodotorula

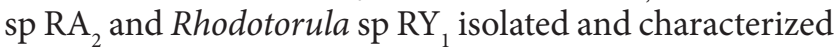
from dairy environmental sources that showed dark pigmentation were used in the present study for extraction of the pigment. The yeast cultures were maintained as slant cultures on Malt Yeast Extract Agar (MYEA) and working cultures in $\mathrm{MYEB}^{6}$ broth with incubation at $30^{\circ} \mathrm{C} / 3-5$ days.

\subsection{Media for Pigment Production}

R.minuta $\mathrm{RAI}_{3}$, R.acheniorum $\mathrm{RC}_{2}$, Rhodotorula sp $\mathrm{RA}_{2}$ and Rhodotorula sp RY, were inoculated to broth media such as sterile MYEB as semi synthetic medium, coconut water as natural medium and rice as natural solid medium and incubated at $30^{\circ} \mathrm{C}$ for $3^{\text {rd }}, 6^{\text {th }}$ and 9 days respectively.

\subsection{Pigment Extraction Method}

Extraction of extracellular and intracellular pigments from R.minuta $\mathrm{RAI}_{3}$, R.acheniorum $\mathrm{RC}_{2}$, Rhodotorula $\mathrm{sp}$ $\mathrm{RA}_{2}$ and Rhodotorula sp RY, was carried out using the following flow chart ${ }^{9}$.

\subsubsection{Extracellular Pigments from Rhodotorula Species}

Inoculated Rhodotorula into $100 \mathrm{ml}$ of culture media MYEB / Coconut water / Rice

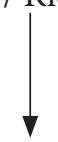

Centrifuged at $6000 \mathrm{rpm}$ for $10 \mathrm{~min}$ and filtered

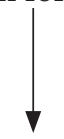

Separated the supernatant for Extracellular Pigment

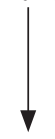

Filter sterilized the supernatant

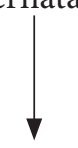

Extracted Pigment from supernatant by using 10ml of acetone as solvent and absorbance was measured at $520 \mathrm{~nm}$.

\subsubsection{Intracellular Pigments from Rhodotorula} Species

Collected all the cell pellets

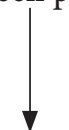

Added $0.1 \mathrm{~N} \mathrm{HCl}(1: 10)$

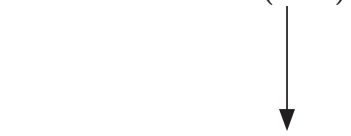

Placed in waterbath at $90^{\circ} \mathrm{C}$ for $10 \mathrm{~min}$

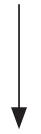

Cooled in ice water for $10 \min \left(37^{\circ} \mathrm{C}\right)$

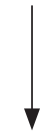

Centrifuged at $6000 \mathrm{rpm}$ for $10 \mathrm{~min}$

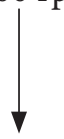

Collected the Supernatant

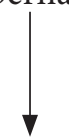

Extracted Pigment from supernatant by using $10 \mathrm{ml}$ of acetone as solvent and absorbance was measured at $520 \mathrm{~nm}$

The yield of the pigment was calculate according to the following formula

$$
\begin{array}{r}
\mathrm{A}_{520}(\text { Absorption at } 520 \mathrm{~nm}) \mathrm{x} \text { volume of the acetone } \\
\text { Carotenoid yield (ug/g of dry cell mass) }= \\
\text { Volume of the } \\
\text { sample } \mathrm{x} 0.17
\end{array}
$$

\section{Results and Discussion}

Production of extracellular carotenoid pigment from Rhodotorula minuta $\mathrm{RAI}_{3}, \mathrm{R}$. acheniorum $\mathrm{RC}_{2}$, Rhodotorula sp $\mathrm{RA}_{2}$ and R.minuta $\mathrm{RY}_{1}$ in MYEB, Coconut water and rice.

Rhodotorula minuta $\mathrm{RAI}_{3}$, R.acheniorum $\mathrm{RC}_{2}$ Rhodotorula sp $\mathrm{RA}_{2}$ and Rhodotorula sp RY, were inoculated to broth media such as sterile MYEB, coconut water and rice as solid medium individually and incubated at $30^{\circ} \mathrm{C}$ for 9 days (Table $1 \&$ Figure 1 ). The pigment production started to visualize from $3^{\text {rd }}$ day onwards 
and intensity was peak on $6^{\text {th }}$ day and later started to fade. Higher production of extracellular pigment was noticed in Rhodotorula minuta $\mathrm{RAI}_{3}$ compared to other Rhodotorula species like R.minuta $\mathrm{RY}_{1}$, Rhodotorula sp $\mathrm{RA}_{2}$ and R.acheniorum $\mathrm{RC}_{2}$ in coconut water, a natural medium i.e. $1.687 \mu \mathrm{g} / \mathrm{g}$ of dry cell mass with viable count of $7.18 \log _{10} \mathrm{cfu} / \mathrm{ml}$ on $6^{\text {th }}$ day at $30^{\circ} \mathrm{C}$. All the three Rhodotorula species produced comparably higher production of pigment in semisynthetic medium MYEB and Rhodotorula acheniorum $\mathrm{RC}_{2}$ produced $2.877 \mu \mathrm{g} / \mathrm{g}$ of dry cell mass with viable count of $7.17 \log _{10} \mathrm{cfu} / \mathrm{ml}$ on sterile rice as solid medium. According to Roadjanakamolson and Suntornsuk (2010) the biomass of Rhodotorula glutinis DM 28 was $54 \mathrm{~g} / \mathrm{kg}$ with $\beta$-carotene content of $1.65 \mathrm{mg} / \mathrm{kg}$ rice bran.

\subsection{Production of Intracellular Carotenoid Pigment from Rhodotorula minuta $\mathrm{RAI}_{3}$, R.acheniorum $\mathrm{RC}_{2}$, Rhodotorula sp $\mathrm{RA}_{2}, R_{\text {.minuta }} \mathrm{RY}_{1}$ in MYEB, Coconut water and Rice}

Rhodotorula minuta $\mathrm{RAI}_{3}$, R.acheniorum $\mathrm{RC}_{2}$, Rhodotorula sp $\mathrm{RA}_{2}$, Rhodotorula sp. $\mathrm{RY}_{1}$ were inoculated to broth media such as sterile MYEB, coconut water and rice as solid medium and incubated at $30^{\circ} \mathrm{C}$ for 9 days (Table 2 $\&$ Figure 2). The pigment production started to visualize from $3^{\text {rd }}$ day onwards and intensity was peak on $6^{\text {th }}$ day and latter started to fade.

Higher production of intracellular pigment was noticed in R.minuta $\mathrm{RAI}_{3}$ compared to species like Rhodotorula

Table 1. Production of extracellular carotenoid pigment from R. minuta $\mathrm{RAI}_{3}$, R. acheniorum $\mathrm{RC}_{2}$, $\mathrm{Rhodotorula}$ sp $\mathrm{RA}_{2}$, and R.minuta $\mathrm{RY}_{1}$, in modified malt yeast extract broth, coconut water and rice

\begin{tabular}{|c|c|c|c|c|c|c|c|}
\hline Type of isolate & Source & $\begin{array}{l}\text { Viable count } \\
\log _{10} \mathrm{cfu} / \mathrm{ml}\end{array}$ & $\begin{array}{l}\text { Extracellular } \\
\text { ( } \mu \mathrm{g} / \mathrm{g} \text { of dry } \\
\text { cell mass) }\end{array}$ & $\begin{array}{l}\text { Viable count } \\
\log _{10} \mathrm{cfu} / \mathrm{ml}\end{array}$ & $\begin{array}{l}\text { Extracellular } \\
\text { ( } \mu \mathrm{g} / \mathrm{g} \text { of dry } \\
\text { cell mass) }\end{array}$ & $\begin{array}{l}\text { Viable count } \\
\log _{10} \mathrm{cfu} / \mathrm{ml}\end{array}$ & $\begin{array}{l}\text { Extracellular } \\
\text { ( } \mu \mathrm{g} / \mathrm{g} \text { of dry } \\
\text { cell mass) }\end{array}$ \\
\hline \multicolumn{2}{|c|}{ Day of incubation } & \multicolumn{2}{|c|}{$3^{\text {rd day }}$} & \multicolumn{2}{|c|}{$6^{\text {th }}$ day } & \multicolumn{2}{|c|}{$9^{\text {th }}$ day } \\
\hline \multirow{3}{*}{ Rhodotorula sp $\mathrm{RA}_{2}$} & MYEB & 7.03 & $0.702(0.364)$ & 7.13 & $0.890(0.520)$ & 7.11 & $0.765(0.493)$ \\
\hline & $\begin{array}{l}\text { Coconut } \\
\text { water }\end{array}$ & 7.03 & $0.388(0.068)$ & 7.06 & $0.514(0.090)$ & 7.05 & $0.451(0.079)$ \\
\hline & Rice & 7.02 & $0.280(0.123)$ & 7.04 & $0.388(0.167)$ & 7.03 & $0.367(0.134)$ \\
\hline \multirow{3}{*}{ R.minuta $\mathrm{RY}_{1}$} & MYEB & 7.09 & $0.817(0.144)$ & 7.12 & $1.259(0.189)$ & 7.11 & $1.137(0.182)$ \\
\hline & $\begin{array}{l}\text { Coconut } \\
\text { water }\end{array}$ & 7.09 & $0.348(0.061)$ & 7.13 & $0.640(0.112)$ & 7.11 & $0.548(0.096)$ \\
\hline & Rice & 7.04 & $0.822(0.143)$ & 7.09 & $1.080(0.270)$ & 7.07 & $1.040(0.199)$ \\
\hline \multirow{3}{*}{ R.minuta $\mathrm{RAI}_{3}$} & MYEB & 7.10 & $0.914(0.186)$ & 7.15 & $1.325(0.685)$ & 7.14 & $1.287(0.671)$ \\
\hline & $\begin{array}{l}\text { Coconut } \\
\text { water }\end{array}$ & 7.09 & $0.691(0.121)$ & 7.18 & $1.200(0.210)$ & 7.16 & $0.965(0.169)$ \\
\hline & Rice & 7.10 & $1.062(0.160)$ & 7.17 & $2.877(0.302)$ & 7.16 & $2.544(0.276)$ \\
\hline \multirow{3}{*}{ R.acheniorum $\mathrm{RC}_{2}$} & MYEB & 7.08 & $0.971(0.186)$ & 7.14 & $1.354(0.271)$ & 7.11 & $1.277(0.215)$ \\
\hline & $\begin{array}{l}\text { Coconut } \\
\text { water }\end{array}$ & 7.12 & $0.862(0.151)$ & 7.18 & $1.678(0.389)$ & 7.14 & $1.342(0.369)$ \\
\hline & Rice & 7.08 & $1.062(0.170)$ & 7.13 & $1.548(0.302)$ & 7.10 & $1.222(0.276)$ \\
\hline
\end{tabular}

Note: For viable count MYEA as used with $\mathrm{pH}$ of 6.0 and incubated at $30^{\circ} \mathrm{C} / 3-5$ days Carotenoid yield ( $\mu \mathrm{g} / \mathrm{g}$ of dry cell mass) $=\mathrm{A}_{520} \mathrm{x}$ volume of the acetone / Volume of the sample $\mathrm{x} 0.17$ Values in the parenthesis indicates the absorbance values at $\mathrm{A}_{520}$ 
Table 2. Production of intracellular carotenoid pigment from R. minuta $\mathrm{RAI}_{3}$, R. acheniorum $\mathrm{RC}_{2}$, Rhodotorula sp $\mathrm{RA}_{2}$ and $R$. minuta $\mathrm{RY}_{1}$ in modified malt yeast extract broth, coconut water and rice

\begin{tabular}{|c|c|c|c|c|c|c|c|}
\hline Type of isolate & Source & $\begin{array}{l}\text { Viable count } \\
\log _{10} \mathrm{cfu} / \mathrm{ml}\end{array}$ & $\begin{array}{c}\text { Extracellular } \\
(\mu \mathrm{g} / \mathrm{g} \text { of dry } \\
\text { cell mass) }\end{array}$ & $\begin{array}{l}\text { Viable count } \\
\log _{10} \mathrm{cfu} / \mathrm{ml}\end{array}$ & $\begin{array}{l}\text { Extracellular } \\
\text { ( } \mu \mathrm{g} / \mathrm{g} \text { of dry } \\
\text { cell mass) }\end{array}$ & $\begin{array}{l}\text { Viable count } \\
\log _{10} \mathrm{cfu} / \mathrm{ml}\end{array}$ & $\begin{array}{l}\text { Extracellular } \\
(\mu \mathrm{g} / \mathrm{g} \text { of dry } \\
\text { cell mass) }\end{array}$ \\
\hline \multirow[b]{2}{*}{ Rhodotorula sp $\mathrm{RA}_{2}$} & MYEB & 7.03 & $1.520(0.103)$ & 7.13 & $1.770(0.124)$ & 7.11 & $1.485(0.094)$ \\
\hline & $\begin{array}{l}\text { Coconut } \\
\text { water }\end{array}$ & 7.03 & $1.090(0.191)$ & 7.06 & $2.160(0.378)$ & 7.05 & $2.120(0.371)$ \\
\hline \multirow{4}{*}{ R.minuta $\mathrm{RY}_{1}$} & Rice & 7.02 & $0.588(0.268)$ & 7.04 & $0.616(0.310)$ & 7.03 & $0.537(0.260)$ \\
\hline & MYEB & 7.09 & $0.405(0.068)$ & 7.12 & $0.651(0.128)$ & 7.11 & $0.451(0.121)$ \\
\hline & $\begin{array}{l}\text { Coconut } \\
\text { water }\end{array}$ & 7.09 & $0.405(0.071)$ & 7.13 & $2.588(0.496)$ & 7.11 & $2.422(0.424)$ \\
\hline & Rice & 7.04 & $0.388(0.070)$ & 7.09 & $0.700(0.114)$ & 7.07 & $0.691(0.079)$ \\
\hline \multirow{3}{*}{ R.minuta $\mathrm{RAI}_{3}$} & MYEB & 7.10 & $1.897(0.233)$ & 7.15 & $3.200(0.705)$ & 7.14 & $3.057(0.676)$ \\
\hline & $\begin{array}{l}\text { Coconut } \\
\text { water }\end{array}$ & 7.09 & $3.840(0.672)$ & 7.18 & $4.412(0.873)$ & 7.16 & $4.274(0.748)$ \\
\hline & Rice & 7.10 & $1.331(0.332)$ & 7.17 & $3.990(0.560)$ & 7.16 & $3.862(0.535)$ \\
\hline \multirow{3}{*}{ R.acheniorum $\mathrm{RC}_{2}$} & MYEB & 7.08 & $0.445(0.082)$ & 7.14 & $1.051(0.153)$ & 7.11 & $0.920(0.142)$ \\
\hline & $\begin{array}{l}\text { Coconut } \\
\text { water }\end{array}$ & 7.12 & $0.405(0.071)$ & 7.18 & $1.091(0.191)$ & 7.14 & $1.062(0.186)$ \\
\hline & Rice & 7.08 & $0.468(0.078)$ & 7.13 & $0.841(0.184)$ & 7.10 & $0.811(0.161)$ \\
\hline
\end{tabular}

Note: For viable count MYEA as used with $\mathrm{pH}$ of 6.0 and incubated at $30^{\circ} \mathrm{C} / 3-5$ days Carotenoid yield $\left(\mu \mathrm{g} / \mathrm{g}\right.$ of dry cell mass) $=\mathrm{A}_{520} \mathrm{x}$ volume of the acetone / Volume of the sample x 0.17 Values in the parenthesis indicates the absorbance values at $\mathrm{A}_{520}$

Table 3. Comparison of pigment production of extracellular and intracellular of $R$. minuta RAI, R. acheniorum $\mathrm{RC}_{2}$, Rhodotorula sp $\mathrm{RA}_{2}$ and Rhodotorula minuta $\mathrm{RY}_{1}$ in modified malt yeast extract broth, coconut water and rice

\begin{tabular}{|c|c|c|c|c|c|c|c|}
\hline \multirow[b]{2}{*}{ Type of isolate } & \multirow[b]{2}{*}{ Source } & \multicolumn{2}{|c|}{$3^{\text {rd day }}$} & \multicolumn{2}{|c|}{$6^{\text {th }}$ day } & \multicolumn{2}{|c|}{$9^{\text {th }}$ day } \\
\hline & & $\begin{array}{c}\text { Extracellular } \\
(\mu \mathrm{g} / \mathrm{g} \text { of dry } \\
\text { cell mass) }\end{array}$ & $\begin{array}{l}\text { Intracellular } \\
\text { ( } \mu \mathrm{g} / \mathrm{g} \text { of dry } \\
\text { cell mass) }\end{array}$ & $\begin{array}{l}\text { Extracellular } \\
\text { ( } \mu \mathrm{g} / \mathrm{g} \text { of dry } \\
\text { cell mass) }\end{array}$ & $\begin{array}{l}\text { Intracellular } \\
\text { ( } \mu \mathrm{g} / \mathrm{g} \text { of dry } \\
\text { cell mass) }\end{array}$ & $\begin{array}{l}\text { Extracellular } \\
\text { ( } \mu \mathrm{g} / \mathrm{g} \text { of dry } \\
\text { cell mass) }\end{array}$ & $\begin{array}{l}\text { Intracellular } \\
\text { ( } \mu \mathrm{g} / \mathrm{g} \text { of dry } \\
\text { cell mass) }\end{array}$ \\
\hline \multirow{3}{*}{ Rhodotorula sp $\mathrm{RA}_{2}$} & MYEB & 0.702 & 1.520 & 0.890 & 1.770 & 0.765 & 1.485 \\
\hline & $\begin{array}{l}\text { Coconut } \\
\text { water }\end{array}$ & 0.388 & 1.090 & 0.514 & 2.160 & 0.451 & 2.120 \\
\hline & Rice & 0.280 & 0.588 & 0.388 & 0.616 & 0.367 & 0.537 \\
\hline \multirow{3}{*}{ R.minuta $\mathrm{RY}_{1}$} & MYEB & 0.817 & 0.405 & 1.259 & 0.651 & 1.137 & 0.451 \\
\hline & $\begin{array}{l}\text { Coconut } \\
\text { water }\end{array}$ & 0.348 & 0.405 & 0.640 & 2.588 & 0.548 & 2.422 \\
\hline & Rice & 0.822 & 0.388 & 1.080 & 0.700 & 1.040 & 0.691 \\
\hline \multirow{3}{*}{ R.minuta $\mathrm{RAI}_{3}$} & MYEB & 0.914 & 1.897 & 1.325 & 3.200 & 1.287 & 3.057 \\
\hline & $\begin{array}{l}\text { Coconut } \\
\text { water }\end{array}$ & 0.691 & 3.840 & 1.200 & 4.412 & 0.965 & 4.274 \\
\hline & Rice & 1.062 & 1.331 & 2.877 & 3.990 & 2.544 & 3.862 \\
\hline \multirow{3}{*}{ R.acheniorum $\mathrm{RC}_{2}$} & MYEB & 0.971 & 0.445 & 1.354 & 1.051 & 1.277 & 0.920 \\
\hline & $\begin{array}{l}\text { Coconut } \\
\text { water }\end{array}$ & 0.862 & 0.405 & 1.678 & 1.091 & 1.342 & 1.062 \\
\hline & Rice & 1.062 & 0.468 & 1.548 & 0.841 & 1.222 & 0.811 \\
\hline
\end{tabular}


minuta $\mathrm{RY}_{1}$ Rhodotorula sp $\mathrm{RA}_{2}$ and R.acheniorum $\mathrm{RC}_{2}$ in coconut water and rice i.e. $4.412 \mu \mathrm{g} / \mathrm{g}$ and $3.990 \mu \mathrm{g} / \mathrm{g}$ of dry cell mass respectively on $6^{\text {th }}$ day at $30^{\circ} \mathrm{C}$.

\subsection{Comparison of Production of Extracellular and Intracellular Carotenoid Pigment from Rhodotorula minuta $\mathrm{RAI}_{3}$, R.acheniorum $\mathrm{RC}_{2}$, Rhodotorula sp $\mathrm{RA}_{2}$, R.minuta $\mathrm{RY}_{1}$ in MYEB, Coconut Water and Rice}

Production of carotenoid pigment from Rhodotorula isolates was more in intracellular rather than extracellular. In case of coconut water, extracellular and intracellular pigment production was maximum on 6th day with absorbance at $520 \mathrm{~nm}$ of $0.210(1.200 \mu \mathrm{g} / \mathrm{g}$ of dry mass $)$ and $0.873(4.412 \mu \mathrm{g} / \mathrm{g}$ of dry mass) in Rhodotorula minuta RAI3 compared to other 3 isolates. It may be due to fatty acids, amino acids, vitamins and minerals that act as growth factor as mentioned by Kaur ${ }^{6}$ and hence coconut water as the naturally available medium can be used as best medium for the extracellular and intracellular pigment production from Rhodotorula. Kaur ${ }^{6}$ has observed maximum extracellular pigment in MYEB supplemented with coconut water at 50: 50 with 0.28 OD of extracellular and 0.75 OD intracellular pigment from Rhodotorula rubra MTCC 1446.

In rice inoculated with Rhodotorula minuta RAI3 incubated at $30{ }^{\circ} \mathrm{C}$ showed OD of $0.302 \mathrm{OD} / \mathrm{ml}(2.877 \mu \mathrm{g} / \mathrm{g}$ of dry cell mass) and 0.560 (3.990 $\mu \mathrm{g} / \mathrm{g}$ of dry cell mass) compared to other 3 isolates. While Roadjanakamolson ${ }^{10}$ used instead of rice, rice bran as solid substrate for pigment production from $R$. glutinis DM 28 and found $\beta$-carotene content of $1.65 \mathrm{mg} / \mathrm{kg}$ rice bran but in present study rice was used as substrate and upon incubation at $30{ }^{\circ} \mathrm{C}$ grains of rice were red like Akshatha( Indian traditional red rice used during rituals).

\section{References}

1. Aksu Z, Tugba AT. Carotenoid production by the yeast Rhodotorula mucilaginosa: use of agricultural wastes as a carbon source. Process Biochem. 2005; 40:2985-91.

2. Deming C, Yonbin H, Zhenxin G. Application of statistical methodology to the optimization of fermentative medium for carotenoids production by Rhodobacter sphaeroides. Process Biochem. 2006; 41:1773-8.

3. Garcia- Malea MC, Brindley C, Del Rio E, Acien FG, Fernandez JM, Molina E. Modelling of growth and accumulation of carotenoids in Haematococcus pluvialis as a function of irradiance and nutrients supply. Biochem Eng J. 2005; 26:107-14.

4. Garrido-Fernandez J, Maldonado-Barragan A, CaballeroGuerrero B, Hornero- Mendez D, Ruiz-Barba JL. Carotenoid production in Lactobacillus plantarum. Int J Food Microb. 2010; 140: 34-9.

5. Iriani RM, Adilma RP, Scamparini, Delia B, Rodriguez A. Selection and characterization of carotenoid-producing yeasts from Campinas region. Braz J Microbiol. 2005; 40:2985-91

6. Kaur B, Chakraborty D, Kaur H. Production and stability Analysis of yellowish pink pigments from Rhodotorula rubra MTCC 1446. Internet J Microbiol. 2009; 7:1.

7. Maldonade IR, Scamparini RPA, Rodriguez-Amaya DB. Selection and characterization of carotenoid-producing yeasts from Campinas region, Brazil. Braz J Microb. 2007; 38:65-70.

8. Po-Fung I, Feng C. Production of astaxanthin by the microalga Chlorella zofingiensis in the dark. Process Biochem. 2005; 40:733-8.

9. Peterson WJ, Bell TA. Etchlls JL, Sart JrWWG. A Procedure for demonstrating the presence of carotenoid pigments in yeasts. 1953; 67.

10. Roadjanakamolson M, Suntornsuk W. Production of $\beta$-Carotene enriched rice bran using solid state fermentation of Rhodotorula glutinis. J Microbiol Biotechnol. 2010; 20(3): 525-31. 